\title{
John Hunter as a Pioneer of Veterinary Science
}

\begin{abstract}
7 HE annual oration of the Royal College of Surgeons commemorating the life and work of John Hunter, was delivered at the Mansion House on February 28, by Sir Frederick Hobday, emeritus professor of surgery, and formerly principal and dean at the Royal Veterinary College. This made a departure from the usual tradition that a member of the medical profession delivers the address.

Sir Frederick Hobday in his introduction remarked that he felt it appropriate that a member of the veterinary profession should be honoured by the invitation to deliver the oration, for John Hunter was one of the founders of the Royal Veterinary College in 1791. He is described as being "the life and soul of the undertaking", and with him were associated Sir John Banks, Sir George Baker, the Duke of Northumberland and certain members of the Odiham Agricultural Society, who collected the necessary funds, and they were instrumental in bringing to England Prof. Charles Vial St. Bel, of the Veterinary School at Lyons, to be the first principal of the London Veterinary College. The early and unexpected death of St. Bel caused much anxiety regarding the future of the College, and Hunter helped to tide over the emergency.

Sir Frederick Hobday then proceeded to review John Hunter's contributions to veterinary science. One of the first operations performed by St. Bel in Great Britain was the removal of accessory feet that grew from the fetlocks of the two fore-legs of a horse, and it is stated that Hunter personally assisted (he was surgeon at St. George's Hospital) and gave St. Bel "some useful and friendly hints". John Hunter was a genuine lover of horses, and has left some excellent advice upon their management and on the proper way to shoe colts in order to correct defects in the manner in which they may use their fore-legs. His observations on what is termed 'roaring' are of particular interest, and although he did not correctly recognize its cause (paralysis of the left laryngeal nerve), he clearly distinguished this condition from 'broken wind'. Hunter wrote, too, "upon the effects that medicines have upon horses", and was untiring in his studies of the anatomy and
\end{abstract}

physiology of animals-from the mouse to the elephant-birds, reptiles, insects and fishes. The illustrations in his book entitled "Certain Parts of the Animal Economy" cannot be surpassed for clear. ness and accuracy even with the aids that are now available. His chapter on the glands between the rectum and bladder, the vesiculæ seminales, describes minutely the comparative anatomy and uses of these glands both in man and in numerous animals, and the alterations that ensue after an animal has been unsexed.

The body temperature of animals was another subject to which John Hunter devoted considerable attention. He performed an experiment in which he froze the edge of the comb of a cockerel and remarks that "when I cut off a little bit it did not bleed nor did the animal show any signs of pain"pioneer work in the use of a freezing mixture as an anæsthetic.

Hunter's writings on digestion bear witness to his keen powers of observation, for he concluded that something secreted in the coat of the stomach acts upon the food and assimilates this to the nature of the blood. He had learnt that it is not possible to make a horse vomit, and recognized the different actions that medicinal agents have upon different species of animals. In regard to the last-named, Sir Frederick remarked that this could have been only through direct observation. Thus, morphine is a narcotic for man and the dog tribe, but produces disastrous delirium in the horse and cat; strychnine and mercurials are much more toxic for the cow and dog than for the horse.

In the realm of surgery, John Hunter's classical experiment of grafting a cock's spur into its comb is well known-definite pioneer work of the various grafting operations that are performed to-day. $\mathrm{He}$ also made a series of observations on the reunion of divided tendons.

In conclusion, Sir Frederick Hobday alluded to the importance to a country of its agriculture, its animals and arable products, and of comparative medicine in the fight against disease, for it is here that the modical man and the veterinary surgeon meet on common ground.

\section{Crystal Structures of the Proteins}

\section{An X-ray Study of Palmer's Lactoglobulin}

By Dr. Dorothy Crowfoot and Dennis Riley, Department of Mineralogy, Oxford

$\mathrm{T}$ HE crystallization of a lactoglobulin from the albumin fraction of cow's milk by Palmer in $1934^{1}$ was notable both for the size and stability of the protein crystals and for their occurrence in two different crystallographic modifications. The stable tabular form occurs alone when salt solutions of the protein are dialysed at an initial $p \mathrm{H}$ of 5.8 followed by adjustment to a $p \mathrm{H}$ of 5.2 with dilute $\mathrm{HCl}$, whilst direct dialysis at a $p H$ of $5 \cdot 2$ against distilled water produces needles which may later recrystallize in the tabular form. We have been able to study the inter-relationship of these two varieties through the kindness of Dr. R. A. Kekwick of the Lister Institute, who gave us preparations of them both. The X-ray measurements show that the two types of lactoglobulin crystals differ not only in crystal structure but also probably in their water content. The tabular crystals are evidently, even on superficial examination, heavily nydrated. They occur commonly either as plates $\{001\}$ up to $0.3 \mathrm{~mm}$. across and bounded by pyramid faces or as prisms elongated along [010] and showing (100) dominating. They prove to be orthorhombic but are very markedly pseudo-tetragonal, and appear isotropic when viewed along the $c$ axis. The birefringence is negative, about $0 \cdot 004$. When these crystals are removed from their 